Jurnal Ilmu Sosial dan Pendidikan (JISIP)

Vol. 6, No. 1 Januari 2022

e-ISSN : 2656-6753, p-ISSN: 2598-9944

DOI: 10.36312/jisip.v6i1.2793/http://ejournal.mandalanursa.org/index.php/JISIP/index

\title{
Analisis Kemampuan Pemecahan Masalah Matematis Siswa Kelas VIII Smp Dalam Menyelesaikan Soal- Soal Geometri Bangun Ruang
}

\author{
Ilham $^{1}$, Faradiba Jabnabillah ${ }^{2}$, Siska Dwi Astiati ${ }^{3}$ \\ ${ }^{1,2,3}$ STKIP Al-Amin Dompu
}

\begin{tabular}{l}
\hline \hline Article Info \\
\hline Article history: \\
Received 03 Januari 2022 \\
Publish 07 januari 2022 \\
\\
\hline Keywords: \\
Mathematical problem solving \\
ability, \\
Solving problems, \\
Geometry of Spatial Building
\end{tabular}

Info Artikel

Article history:

Diterima 03 januari 2022

Publis 07 januari 2022

\begin{abstract}
Students' mathematical problem solving ability is one thing that must be considered. This is because when students are given problem solving problems in the form of routine students are able to solve these problems, but if a non-routine problem arises, students will have difficulty. During teaching and learning activities students are able to solve problems when presented with questions of the same type. However, if given a variety of questions, some students have difficulty working on them. This study aims to explore and describe students' mathematical problem solving abilities in solving spatial problems. This study uses a descriptive qualitative approach. The data analysis technique in this study used descriptive analysis techniques. The results of the analysis show that high-ability subjects can understand the problem by writing steps, solving problems, re-examining the results of work very precisely and correctly. Students with moderate abilities can only solve problems without writing what is known and asked. Meanwhile, lowability students cannot fulfill all aspects of mathematical problem solving.

\begin{tabular}{l}
\hline ABSTRAK \\
\hline Kemampuan pemecahan masalah matematis siswa menjadi salah satu hal yang \\
harus diperhatikan. Hal ini dikarenakan ketika siswa diberikan soal pemecahan \\
masalah yang berbentuk rutin siswa mampu untuk menyelesaikan persoalan \\
tersebut, akan tetapi jika muncul suatu permasalahan yang non-rutin maka siswa \\
akan mengalami kesulitan. Pada saat kegiatan belajar mengajar siswa mampu \\
menyelesaikan permasalahan apabila disajikan soal-soal dengan tipe yang sama. \\
Akan tetapi, jika diberikan soal yang bervariasi sebagian siswa mengalami kesulitan \\
dalam mengerjakannya. Penelitian ini bertujuan untuk mengeksplorasi dan \\
mendeskripsikan kemampuan pemecahan masalah matematis siswa dalam \\
menyelesaikan soal- soal bangun ruang. Penelitian in menggunakan pendekatan \\
kualitatif yang bersifat deskriptif. Teknik analisis data dalam penelitian ini \\
menggunakan teknik analisis deskriptif. Hasil analisis menunjukan subjek yang \\
berkemampuan tinggi dapat memahami masalah dengan cara menulis langkah - \\
langkah, menyelesaikan soal, memeriksa kembali hasil pekerjaan dengan sangat \\
tepat dan benar. Siswa berkemampuan sedang hanya dapat menyelesaikan soal saja \\
tanpa menulis yang diketahui dan ditanyakan. Sedangkan siswa berkemampuan \\
rendah tidak dapat memenuhi semua aspek dalam pemecahan masalah matematis.
\end{tabular}
\end{abstract}

This is an open access article under the Lisensi Creative Commons Atribusi-
BerbagiSerupa 4.0 Internasional

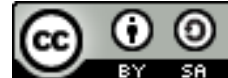

\author{
Corresponding Author: \\ Ilham \\ STKIP Al-Amin Dompu \\ Email: ilhamstkipalamindompu@gmail.com,
}




\section{PENDAHULUAN}

Matematika merupakan salah satu mata pelajaran yang dipelajari disetiap jenjang pendidikan, dari jenjang sekolah dasar hingga perguruan tinggi. Salah satu fungsi diberikannya mata pelajaran matematika adalah sebagai alat untuk memecahkan masalah baik dalam mata pelajaran lain, dalam dunia kerja, maupun dalam kehidupan sehari-hari. Hal ini dikarenakan menurut Tangio (2015). Matematika juga merupakan ilmu yang mempelajari tentang perhitungan, pengkajian dan menggunakan nalar atau kemampuan berfikir seseorang secara logika dan pikiran yang jernih. Pemecahan masalah sangat penting dalam pembelajaran matematika, karena proses pemecahan masalah akan menjadikan pemahaman siswa lebih baik dan memberikan manfaat yang besar kepada siswa dalam melihat relevansi antara matematika dengan mata pelajaran yang lain, serta dalam kehidupan nyata. Menurut Branca (Sumartini, 2016). Sirait (2017) juga menyatakan bahwa kemampuan siswa dalam menyelesaikan masalah matematika dengan memperhatikan proses menemukan jawaban berdasarkan langkah-langkah pemecahan masalah yaitu memahami masalah merencanakan pemecahan masalah; dan melakukan pengecekan kembali. oleh karena itu Proses pembelajaran matematika mampu melatih berpikir seseorang secara logis, kritis, dan kreatif selain itu matematika merupakan ilmu dasar dari perkembangan sains dan sangat berguna dalam kehidupan. Pada setiap lapisan masyarakat seperti apapun profesi dan pekerjaanya tetap dituntut untuk mengetahui matematika kemudian berupaya untuk belajar dan memahaminya Mengingat pentingnya pemecahan masalah dalam pembelajaran matematika, maka kemampuan tersebut akan didukung dengan bagaimana memahami kemampuan tersebut dengan baik agar tujuan yang diinginkan tercapai.

Pemecahan masalah merupakan kemampuan yang essensial dan fundamental, karena kemampuan ini mendasar dan sangat penting yang harus dimiliki oleh semua orang (Mariam, 2019). Pemecahan masalah melatih para siswa untuk menguasai kemampuan atau skill berfikir tingkat tinggi seperti kemampuan berfikir kreatif dan kemampuan berfikir kritis, siswa harus memiliki kemampuan pemecahan masalah matematika terlebih dahulu. Rambe (2020) juga menyatakan Kemampuan pemecahan masalah juga merupakan kemampuan siswa dalam memecahkan masalah yang kompleks dan nonrutin. siswa dapat memahami masalah yang kompleks tersebut dan menyusun rencana pemecahan masalah tersebut sehingga akhirnya siswa dapat menentukan solusi dari masalah yang kompleks dan non rutin tersebut. Sebagaimana yang dinyatakan oleh Polya (1973) terdapat empat langkah yang dilakukan siswa dalam memecahkan masalah, yaitu (1) memahami masalah; (2) merencanakan stratgei pemecahan masalah; (3) melaksanakan strategi pemecahan masalah, dan (4) mengecek kembali solusi yang diperoleh. Jadi seseorang dikatakan memiliki kemampuan pemecahan masalah yang baik yaitu seseorang yang mampu memahami informasi yang terdapat pada masalah secara utuh dan menggunaan informasi tersebut untuk menyusun strategi pemecahan masalah dan memecahkan masalah tersebut.

Hal ini sejalan dengan hasil observasi yang dilakukan di SMP 06 Soromandi. Berdasarkan hasil observasi awal bahwa kemampuan pemecahan masalah matematis siswa kelas VIII belum optimal hal ini peneliti dapatkan dari hasil observasi dan wawancara. Menurut guru yang peneliti wawancarai kemampuan pemecahan masalah matematis siswa menjadi salah satu hal yang harus diperhatikan. Hal ini dikarenakan ketika siswa diberikan soal pemecahan masalah yang berbentuk rutin siswa mampu untuk menyelesaikan persoalan tersebut, akan tetapi jika muncul suatu permasalahan yang non-rutin maka siswa akan mengalami kesulitan. Pada saat kegiatan belajar mengajar siswa mampu menyelesaikan permasalahan apabila disajikan soal-soal dengan tipe yang sama. Akan tetapi, jika diberikan soal yang bervariasi sebagian siswa mengalami kesulitan dalam mengerjakannya. Masih banyak siswa yang hanya mampu melaksanakan pada tahap awal yaitu menuliskan hal yang diketahui saja. Sedangkan pada tahap 
selanjutnya para siswa kebingungan sehingga tidak menjawab soal yang diberikan atau mencari jalan keluar dengan meminta jawaban dari teman sekelasnya.

Berdasarkan paparan tersebut adapun tujuan dari penelitian ini adalah untuk mengeksporasi dan mendeskripsikan kemampuan pemecahan masalah matematis siswa SMP 06 Soromandi dalam menyelesaikan soal- soal bangun ruang. Sedangkan aspek yang digunakan dalam penelitian ini ditinjau dari langkah pemecahan masalah matematis yang dijelaskan oleh Polya. (1) Memahami masalah, Aspek yang harus dicantumkan mahasiswa pada langkah ini meliputi apa yang diketahui dan apa yang ditanyakan, (2) Merencanakan penyelesaian, Aspek yang harus dicantumkan mahasiswa pada langkah ini meliputi urutan langkah penyelesaian dan mengarahkan pada jawaban yang benar; (3) Menyelesaikan rencana penyelesaian, Aspek yang harus dicantumkan mahasiswa pada langkah ini meliputi pelaksanaan cara yang telah dibuat dan kebenaran langkah yang sesuai dengan cara yang dibuat; (4) Memeriksa kembali, Aspek yang harus dicantumkan mahasiswa pada langkah ini meliputi penyimpulan jawaban yang telah diperoleh dengan benar/memeriksa jawabannya dengan tepat.

\section{Jenis dan Pendekatan Penelitian}

Sesuai dengan tujuan peneliti untuk menganalisis kemampuan pemecahan masalah matematis, maka jenis penelitian yang digunakan adalah penelitian deskriptif. Sedangkan Pendekatan yang digunakan dalam penelitian ini yaitu pendekatan kualitatif. Penelitian ini dilaksanakan di SMPN 06 Soromandi kelas VII yang beralamat di desa punti Kabupaten Bima. Agar mengikuti kurikulum dan jadwal yang ada di sekolah yang menjadi lokasi penelitian, maka penelitian ini akan dilaksanakan dari bulan Agustus 2021.

Subyek dalam penelitian ini adalah siswa kelas VII SMPN 06 Soromandi Tahun Pelajaran 2020/2021 yang terdiri dari siswa 12 siswa laki-laki dan 8 siswa perempuan, sehingga jumlah keseluruhannya adalah 20 siswa.untuk di analisis lebih mendalam. Sedangkan objek yang diteliti adalah kemampuan pemecahan masalah matematis siswa. Data dalam penelitian ini adalah data yang dikumpulkan secara langsung oleh peneliti yaitu berupa hasil pengerjaan siswa pada lembar tes tentang kemampuan pemecahan masalah matematis. Sedangkan sumber data dalam penelitian ini adalah siswa kelas VII SMPN 06 Desa Punti

Sesuai dengan tujuan peneliti untuk menganalisis kemampuan pemecahan matematis, maka jenis penelitian yang digunakan adalah penelitian deskriptif. Sedangkan Pendekatan yang digunakan dalam penelitian ini yaitu pendekatan kualitatif. Penelitian ini dilaksanakan di SMPN 06 Desa Punti. Namun peneliti memilih 3 orang siswa yang diambil dari setiap kelompok dengan kategori tinggi $(\mathrm{T})$, sedang $(\mathrm{S})$ dan rendah $(\mathrm{R})$ untuk di analisis lebih mendalam. Sedangkan objek yang diteliti adalah kemampuan pemecahan masalah matematis. Data dalam penelitian ini adalah data yang dikumpulkan secara langsung oleh peneliti yaitu berupa hasil pengerjaan siswa pada lembar tes tentang kemampuan pemecahan masalah matematis. Sedangkan sumber data dalam penelitian ini adalah siswa kelas VII SMPN 06 Desa Punti.

\section{Hasil Analisis Subjek Berkemampuan Tinggi}

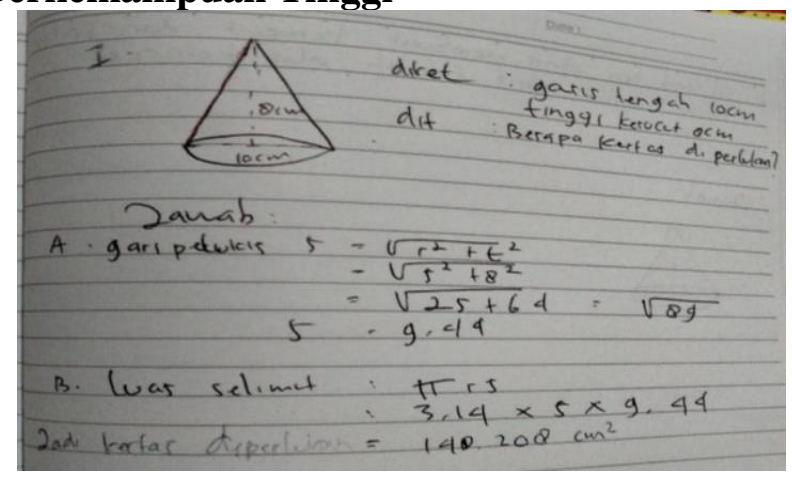


Memperhatikan hasil pekerjaan siswa $\mathrm{T}$ pada aspek memahami masalah diketahui siswa dapat menuliskan yang diketahui maupun yang ditanyakan dengan sangat benar, pada aspek Merencanakan penyelesaian, terlihat jelas dari hasil pengerjaan siswa bahwa siswa dapat merencanakan penyelesaian dengan cara mencari garis pelukisnya dengan sangat benar. Kemudian pada aspek Aspek langkah penyelesaian siswa dapat menuutkan langah penyelesaian dengan sangat benar, dimulai memahami pertayaan hingga menyusun penyelesain dengan sangat benar. Selanjutnya pada aspek ketiga terlihat jelas dari jawaban siswa sangat benar dan mudah Menyelesaikan rencana penyelesaian. Pada aspek terakhir memeriksa kembali, siswa dapat penyimpulan jawaban yang telah diperoleh dengan benar/memeriksa jawabannya dengan tepat. Jadi dapat disimpulkan bawa siswa dengan kemampuan $\mathrm{T}$ dapat memenuhi keempat aspek tersebut dengan sangat benar dan tepat.

\section{Hasil Analisis Subjek Berkemampuan Sedang}

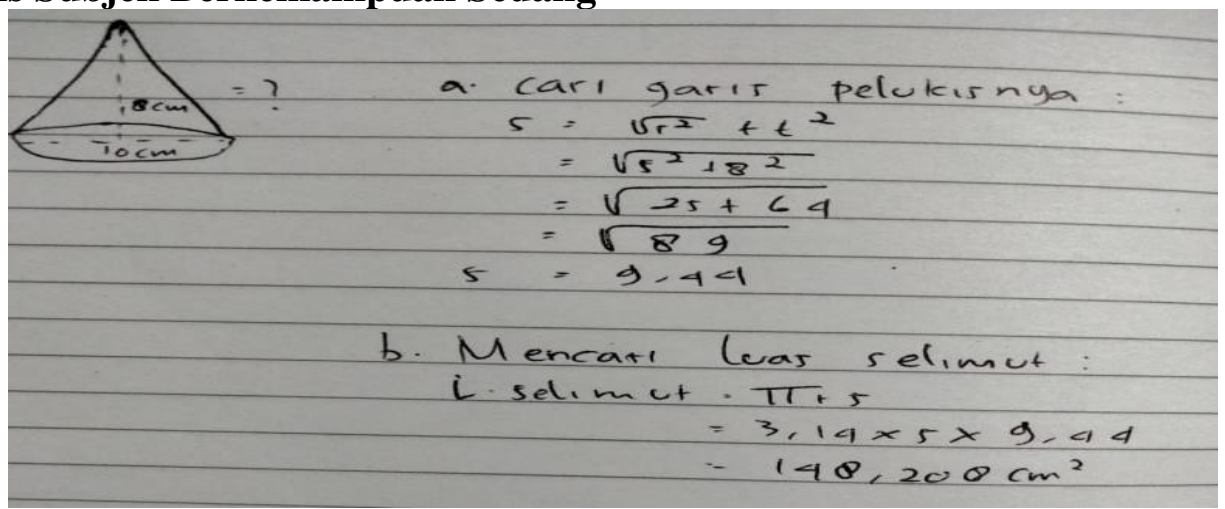

Memperhatikan hasil pekerjaan $S$ pada aspek memahami masalah (1) Memahami masalah, diketahui siswa tidak dapat menuliskan yang diketahui maupun yang ditanyakan yang mengakibatkan siswa tersebut tidak memenuhi aspek memahami masalah, namun pada aspek Merencanakan penyelesaian, terlihat jelas dari hasil pengerjaan siswa bahwa siswa dapat merencanakan penyelesaian dengan cara mencari garis pelukisnya dengan sangat benar. Kemudian pada aspek Aspek langkah penyelesaian siswa dapat menuutkan langah penyelesaian dengan sangat benar, dimulai memahami pertayaan hingga menyusun penyelesain dengan sangat benar. Selanjutnya pada aspek ketiga terlihat jelas dari jawaban siswa sangat benar dan mudah Menyelesaikan rencana penyelesaian. Pada aspek terakhir memeriksa kembali, siswa dapat penyimpulan jawaban yang telah diperoleh dengan benar/memeriksa jawabannya dengan tepat.

\section{Hasil Analisis Subjek Berkemampuan Rendah}

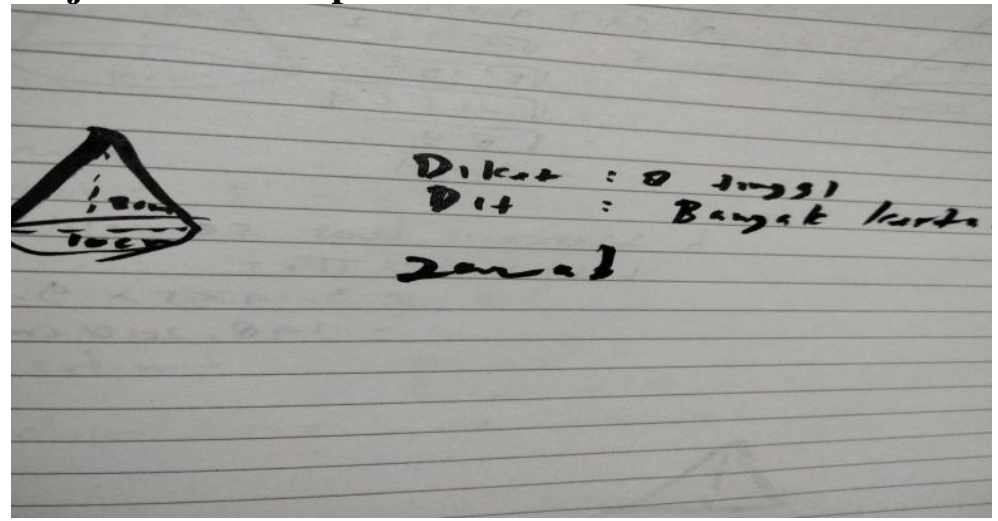

Memperhatikan hasil pekerjaan siswa $\mathrm{R}$ pada aspek memahami masalah (1) Memahami masalah, diketahui siswa tidak dapat menuliskan yang diketahui maupun yang ditanyakan dengan sangat benar yang mengakibatkan siswa tersebut tidak memenuhi aspek memahami masalah, aspek Merencanakan penyelesaian, terlihat jelas dari hasil pengerjaan siswa bahwa 
siswa tidak dapat merencanakan penyelesaian dengan cara mencari garis pelukisnya. Kemudian pada aspek Aspek langkah penyelesaian siswa tidak dapat menemukan langah penyelesaian dengan sangat benar, hal itu dapat dilihat dari hasil pengerjaan siswa bahwa siswa tidak dapat meencanakan penyelesaikan maupun mnyusun penyelesaian. Disimpulkan bahwa siswa pada kategori R tidak dapat memenuhi keempat aspek.

\section{HASIL DAN PEMBAHASAN}

Siswa berkemampuan pemecahan masalah matematis tinggi, memiliki kecenderungan dapat memahami masalah dengan mengetahui dan menuliskan apa yang diketahui dan apa yang ditanyakan dalam soal dengan lengkap. Selanjutnya siswa yang berkemapuan tinggi merencanakan penyelesaian dapat dapat melaksanakan satu strategi benar dengan tepat dan sistematis serta dapat menuliskan hasil akhir yang benar disertai satuan, melakukan pemeriksaan pada setiap langkah strategi pemecahan masalah terhadap perhitungan dan memberikan alasan terhadap kebenaran solusi. Siswa berkemampuan sedang dalam pemecahan masalah tidak dapat memenuhi aspek pertama yaitu menuliskan yang diketahui dan ditanyakan. Selanjutnya pada aspek yang kedua dimana siswa berkemampuan pemecahan masalah matematis sedang dapat merencanakan penyelesaian dengan cara menulis langkah- langkah penyelesaian dengan sangat benar. Pada Aspek menyelesaikan rencana penyelesaian siswa dapat menyelesaikan soal dengan sangat tepat dan lengkap. Terakhir pada aspek memeriksa kembali dimana siswa dapat menyimpulkan jawaban yang diperoleh dengan benar.

Siswa berkemampuan Siswa berkemampuan rendah dalam pemecahan masalah tidak dapat memenuhi aspek yaitu menuliskan yang diketahui dan ditanyakan dengan benar. Selanjutnya pada aspek yang kedua dimana siswa berkemampuan pemecahan masalah matematis rendah tidak dapat merencanakan penyelesaian dengan cara menulis langkah- langkah penyelesaian dengan sangat benar. Pada Aspek menyelesaikan rencana penyelesaian siswa tidak dapat menyelesaikan soal maupun menyusun langkah- langkahnya. Terakhir pada aspek memeriksa kembali dimana siswa tidak dapat menyimpulkan jawaban yang diperoleh dengan benar karena siswa tidak dapat menyelesaikan soal.

Hal demikian sejalan dengan hasil penelitian (Pangestu, 2021). Dimana siswa yang berkemampuan pemecahan masalah matematis pada materi perbandingan, angket disposisi matematis, dan wawancara kemampuan pemecahan masalah matematis. Instrumen angket dan tes yang digunakan sudah di uji validitas dan reliabilitas serta divalidasi oleh validator ahli. Hasil penelitian menunjukkan bahwa disposisi matematis siswa kelas VII-A SMPN 280 Jakarta terbagi menjadi tiga tingkat yaitu tinggi, sedang, dan rendah. Siswa yang memiliki disposisi matematis tinggi memiliki kemampuan pemecahan masalah matematis yang lebih baik. Siswa yang memiliki disposisi matematis sedang kurang mampu memenuhi indikator meninjau kembali pemecahan masalah. Siswa yang memiliki disposisi matematis rendah tidak mampu memenuhi semua indikator kemampuan pemecahan masalah matematis.

Penelitian roswanti (2020) juga sejalan dengan hasil pnelitian diatas dimana Hasil penelitian menunjukkan bahwa: (1) Kemampaun pemecahan masalah berdasarkan langkah-langkah Polya pada subjek berkemampuan rendah dengan menggunakan model pembelajaran Creative Problem Solving ( CPS ) yaitu (1) subyek berkemampuan matematis rendah belum dapat memehami masalah dengan baik, subyek berkemampuan matematis rendah kurang tepat memodelkan kalimat matematika yang ada pada soal.(2)Subjek berkemampuan matematis rendah tidak bisa membuat rencana penyelesaian, subjeklangsung melakukan penyelesaian masalah tanpa membuat rencana penyelesaian terlebih dahulu dalam menyelesaikan masalah dan jawabanyang diperoleh oleh subjek berkemampuan matematis rendah tidak tepat, hal tersebut karena subjekmelakukan kesalahan dalam memodelkan kalimat matematika. (3) Subjekberkemampuan matematis rendah juga tidak dapat memeriksa kembali jawaban yang sudah ia peroleh. Dari hasil penelitian disimpulkan bahwa 
subjek berkemampuan rendah yaitu subjek RPR pada tes pertama dan kedua subyek tidak mampu melakukan tahap-tahap pemecahan masalah dengan baik. Hal ini menyebabkan subyek secara konsisten tidak mampu menjawab permasalahan dengan baik dalam waktu yang berbeda.

\section{KESIMPULAN}

Hasil analisis menunjukan subjek yang berkemampuan tinggi dalam pemecahan masalah dapat memenuhi aspek memahami masalah, dengan menuliskan yang diketahui dan ditanyakan. Selanjutnya pada aspek yang kedua dimana siswa berkemampuan pemecahan masalah matematis dapat merencanakan penyelesaian dengan cara menulis langkah- langkah penyelesaian dengan sangat benar. Pada Aspek menyelesaikan rencana penyelesaian siswa dapat menyelesaikan soal dengan sangat tepat dan lengkap. Terakhir pada aspek meeriksa kembali dimana siswa dapat menyimpulkan jawaban yang diperoleh dengan benar.

Siswa berkemampuan sedang dalam pemecahan masalah tidak dapat memenuhi aspek pertama yaitu menuliskan yang diketahui dan ditanyakan. Selanjutnya pada aspek yang kedua dimana siswa berkemampuan pemecahan masalah matematis sedang dapat merencanakan penyelesaian dengan cara menulis langkah- langkah penyelesaian dengan sangat benar. Pada Aspek menyelesaikan rencana penyelesaian siswa dapat menyelesaikan soal dengan sangat tepat dan lengkap. Terakhir pada aspek memeriksa kembali dimana siswa dapat menyimpulkan jawaban yang diperoleh dengan benar.

Siswa berkemampuan Siswa berkemampuan rendah dalam pemecahan masalah tidak dapat memenuhi aspek yaitu menuliskan yang diketahui dan ditanyakan dengan benar. Selanjutnya pada aspek yang kedua dimana siswa berkemampuan pemecahan masalah matematis rendah tidak dapat merencanakan penyelesaian dengan cara menulis langkah- langkah penyelesaian dengan sangat benar. Pada Aspek menyelesaikan rencana penyelesaian siswa tidak dapat menyelesaikan soal maupun menyusun langkah- langkahnya. Terakhir pada aspek memeriksa kembali dimana siswa tidak dapat menyimpulkan jawaban yang diperoleh dengan benar karena siswa tidak dapat menyelesaikan soal.

\section{SARAN}

Adapun saran yang dari penelitian ini, guru harus benar- benar memperhatikan dan meningkat kemampuan matematika siswa. Dengan cara menerapkan metode pembelajaran yang tepat guna melatih daya berfikir siswa dalam menyelesaikan masalah. Selain itu, guru juga diminta untuk sering melatih siswa dengan memberikan soal yang bervariasi yang dapat mengasah kemampuan siswa agar siswa terbiasa menyelesaikan soal- soal tersebut.

\section{DAFTAR PUSTAKA}

Mariam, S., Nurmala, N., Nurdianti, D., Rustyani, N., Desi, A., \& Hidayat, W. (2019). Analisis kemampuan pemecahan masalah matematis siswa mtsn dengan menggunakan metode open ended di Bandung Barat. Jurnal Cendekia: Jurnal Pendidikan Matematika, 3(1), 178-186.

Pangestu. (2021). Analisis Kemampuan Pemecahan Masalah Matematis Siswa Pada Materi Perbandingan Ditinjau Dari Disposisi Matematis. Jurnal Cendekia: Jurnal Pendidikan Matematika: Volume 5 Nomor 2, In press

Polya, G. (1973). How to Solve It (2nd ed.). New Jersey: Prence University Press

Rambe, F.Y \& Afri, D.L. (2020). Analisis Kemampuan Pemecahan Masalah Matematis Siswa Dalam Menyelesaikan Soal Materi Barisan Dan Deret. Jurnal Pendidikan dan Matematika, 175-187

Rendah Pada Pembelajaran Creative Problem Solving. Jurnal matematika dan pendidikan Matematika. Vol 2, No 3

Rosnawati. (2020). Kemampuan Pemecahan Masalah Siswa Berkemampuan Matematis 
Sirait, S. \& Purba, O. 2017. Peningkatan Kemampuan Pemecahan Masalah Pada Materi Trigonometri Dengan Model LAPS-Heuristic Pada kelas X SMA Shafiyyatul Amaliyah. Prosiding Seminar Nasional Multidisiplin Ilmu UNA 2017. ISBN 978- 6025039-1-4.

Sumartini, T. S. (2016). Peningkatan Kemampuan Pemecahan Masalah Matematis Siswa melalui Pembelajaran Berbasis Masalah. Jurnal Pendidikan Matematika,

Tangio, N. F. (2015). Deskripsi Kemampuan Pemecahan Masalah Matematika Pada Materi Soal Cerita Penjumlahan Dan Pengurangan Bilangan Bulat Dikelas VII SMP Negeri 1 Tapa. Jurnal Pendidikan Matematika 